\title{
Estimation of the tourist carrying capacity of the Natural Reserve Mombacho Volcano, Granada, and the Natural Reserve Datanlí-EI Diablo, Jinotega, Nicaragua
}

\author{
M. Somarriba-Chang, M. Garnier \& V. Laguna \\ Universidad Nacional Agraria, Nicaragua
}

\begin{abstract}
The study was undertaken in the Natural Reserve Mombacho Volcano (NRMV), Granada and the Natural Reserve Cerro Datanlí-El Diablo (NRDE), Jinotega. The main objectives of this research were to analyze the current tourism management in the sites, to determine the visitor carrying capacity for the walking trails and give recommendations for managing visitors in the sites.

The visitor carrying capacity (VCC) works as a potential strategy to reduce recreational impacts in Natural Protected Areas [5]. Visitor carrying capacity is considered at three consecutive levels: physical carrying capacity (PCC), real carrying capacity (RCC) and effective carrying capacity (ECC) [3]. The PCC was estimated based on the dimension of each trail, the space needed for each visitor and the time required to walk it. The RCC involves correction factors such as distance between groups, soil erodability, difficulty to walk, and others. The ECC includes the Management Capacity (MC), which is given by the existence of appropriate personnel, equipment and facilities in the protected area [3]. The MC of the NRMV estimated was $74.24 \%$. If the MC increases to $80 \%$ because of improvement in any of its components; the ECC would increase in the same proportion. According to Fundación Cocibolca, the organization managing the NRVM, scholar visitors show a different behaviour than ecotourism visitors. This rationale was considered in the calculation of the correction factors. This gave a much lower ECC for students. Therefore the maximum number of visits registered exceed the ECC calculated for students but not for ecotourists. If the trend of visits continues to increase in the following years, it will be necessary to restrict the number of visits during the top periods.

On the other site, the peak El Gobiado, North sector of the NRDE has 3 defined walking trails: El Congo, El León and Campanero. The MC was $62.34 \%$ of the optimum. The scenario of MC at $80 \%$ would increase the ECC even more than in the NRMV case. It is suggested that this research could be used by the Ecotourism Project, funded by PNUD and further developed by PAGJINO applying the recommendations for visitor management on the walking trails, fauna species indicators for impact monitoring in the site, and training local tourist guides for visitor management.
\end{abstract}

Keywords: protected areas, ecotourism, visitor carrying capacity, physical carrying capacity, management capacity, real carrying capacity, effective carrying capacity, MARENA, SINAP, Fundación Cocibolca and PAGJINO. 


\section{Introduction}

Protected areas in Nicaragua embrace $18 \%$ of the national territory [7]. The management plans approved by SINAP in MARENA contemplate the possibility of low impact tourism activities in the protected areas, such as Ecotourism. This is considered a type of alternative tourism, characterized as an experience to visit natural areas in order to understand its natural history and local culture, with the support of environmental interpretation and education [1].

The main forms of ecotourism activities developed in Nicaragua are: agro tourism, research or scientific tourism; and nature tourism. The activities happening on these modalities consist of visits to terrestrial landscapes and various types of ecosystems; and visits to volcanic, marine, coastal and insular landscapes. All of them involve the interaction between the setting and culturalnatural environments [9].

In order to determine the tourism carrying capacity (TCC) of a specific site, it is necessary to know the relationship between the management parameters of the area and the dynamic of the impacts caused by the activities that are developed in the area. In this way, it is possible to take decisions regarding TCC. This works as a potential strategy to reduce the impacts of recreation caused by the visitors in natural protected areas [5].

\section{General objective}

To provide recommendations to the managers of the sites based on the visitor carrying capacity for the walking trails in the Natural Reserves Mombacho Volcano, Granada; and Datanlí - El Diablo, Jinotega, Nicaragua.

\section{Methodology}

\subsection{Location of the two natural reserves}

The NRMV is located in the department of Granada $10 \mathrm{~km}$ from Granada city and $50 \mathrm{~km}$ from Managua (Figure 1). The geographic coordinates are $11^{\circ} 50^{\text {' }}$ North and $85^{\circ} 59^{\prime}$ 'West, the highest elevation is 1,345 masl. The area of this reserve is approximately 578 hectares [4]. This area is under the system of comanagement; Fundación Cocibolca is a NGO in charge of co-managing this reserve along with the Ministry of Environment and Natural Resources (MARENA).

The NRDE is located in the department of Jinotega in the North- Central region of Nicaragua (Figure 1). It has an area of 5,849 hectares $\left(58.49 \mathrm{~km}^{2}\right)$. The geographic coordinates are $13^{\circ} 04^{\prime} 42.1^{\prime \prime}$ and $13^{\circ} 10^{\prime} 10.7^{\prime \prime}$ North and $85^{\circ} 49^{\prime}$ 49.4" and $85^{\circ} 54^{\prime}$ 58.6" West, the highest elevation is 1,650 meters above sea level (masl) [7]. The NRDE has 145 land owners who have different types of land use on their farms. MARENA is in charge of guiding them to accomplish the appropriate practices in accordance with the management plan of the NRDE approved. 


\subsection{Main climatic characteristics in the two protected areas}

\subsubsection{Natural Reserve Mombacho Volcano}

The mean annual precipitation ranges from 1,200 to $1,800 \mathrm{~mm}$. It varies according to the altitude. Precipitation can be in form of mist that is maintained during the day, especially during the rainy season. The mean annual temperature at the base of the volcano is around $27^{\circ} \mathrm{C}$ and goes down approximately $1{ }^{\circ} \mathrm{C}$ for every $150 \mathrm{~m}$ of elevation [4].

\subsubsection{Natural Reserve Datanlí-EI Diablo}

The mean annual precipitation goes from 1,650 in the north zone, to $2,500 \mathrm{~mm}$ in the southern part of the reserve. Like the NRMV the main rainy season lasts from May to November, but all year long some rain occurs (MARENA et al. [6, 7]). The mean annual temperature varies according to altitude, at 1,000 masl it is around $20^{\circ} \mathrm{C}$; in the zone with the highest elevation, which is about 1,600 masl it is $12.5^{\circ} \mathrm{C}$. There are very small differences over the year; it varies up to $2^{\circ} \mathrm{C}$ from the hottest to the coolest months [6].
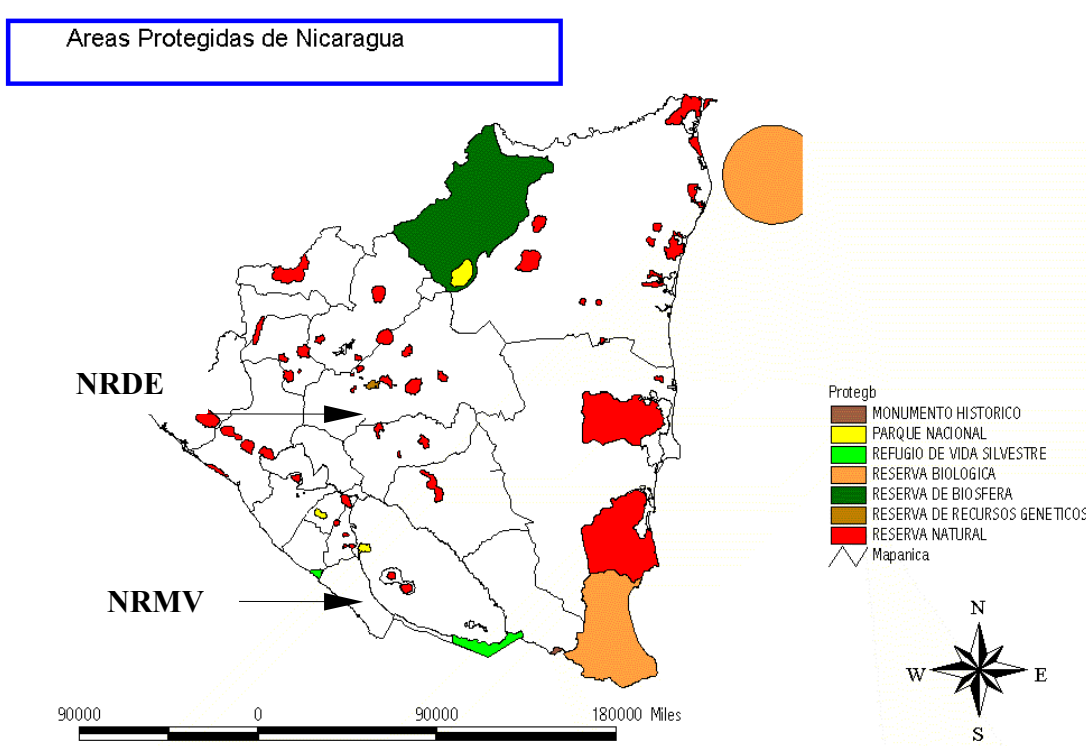

Figure 1: $\quad$ Protected areas in Nicaragua and location of the Natural Reserves Mombacho Volcano (NRMV), Granada and Datanlí-El Diablo (NRDE), Jinotega (source: SINIA, 2004). 


\subsection{Natural vegetation and current land uses in the protected areas}

\subsubsection{Natural Reserve Mombacho Volcano}

The elf forest is located between 1,200 and 1,344 masl. This forest borders on the cloud or misty forest, which is observed from 860 to 1,200 masl. At a lower altitude the Semi deciduous forest, which ranges from 590 masl up to 900 masl takes over. The dry forest is found at the lowest elevation of the volcano [4].

The main economic activity is agriculture. Basically, coffee plantations under different agro forestry systems are found. This ranges from rustic shade coffee to specialized shade. Another major activity is stock-cattle which are taking place mostly in the lowest parts of the volcano hillsides [4].

\subsubsection{Natural Reserve Datanlí-EI Diablo}

The reserve is classified as a cloud or misty forest. But because the area has been subject to different type of land uses, the forest cover varies as follows: $58 \%$ is actually covered by forest $(3,400 \mathrm{ha})$. Dense forest occupies $49 \%$ of the area (2,860 ha) and the so-called "open forest" comprises $9 \%$ (545 ha) of the territory. However, forest cover has suffered different kinds of degradation, fragmentation and perturbation. They may be reduced to very small areas eventually [6].

There are four land use types, besides forest areas. They are: coffee plantations, pastures, annual crop areas and fallow areas. Coffee plantations have an area of 816 ha, pastures 610 ha, fallow areas 460 ha and annual crop areas 556 ha (staple crops and vegetables). Most of the land is privately owned, with the exception of the territory that holds a military base in the southern part of the NRDE, which belongs to the government [6].

\subsection{Brief description of the walking trails in the two natural reserves}

\subsubsection{Natural Reserve Mombacho Volcano}

"El Crater": This is the most popularly visited in the site. It has a length of 1,500 meters; it can be hiked by tourists without a park ranger or tourist guide, because it has interpretative signals along it. The major attractive features are the tunnel and the fumaroles; it offers great appreciation of elf forest and a variety of bromeliads.

"El Puma": The trail has an extension of 4,000 meters. It has four magnificent viewers: La Roca, Los Vientos, La Avalancha and La Cueva. This is the most difficult trail to hike because of steep slopes. The entrance to this trail is only allowed with a tourist guide, who has been requested by the tourist to the administrators of the NRMV in advance.

"El Cafetal": This is the only walking trail located at the foot of the volcano, right at the parking area. The main attractions of this trail are to watch birds and butterflies.

\subsubsection{Natural Reserve Datanlí-EI Diablo}

"El Leon": This trail has a distance of 1,722 meters and is connected to the walking trail El Congo a few meters away from the fall creek having a common 
exit to both trails. At the beginning of this trail the "love stone" is located. The stone is connected with a legend told by the locals. There is also an eye-catching view of the Apanas Lake at this place. Furthermore there is a great variety of vegetation, birds, butterflies, and different small and medium mammals that can be watched walking along this trail. The name was given by the residents, because a "lion" moves around in this site.

"El Congo": This trail has a distance of 2,575 meters, including the segment that is common to the trail El Leon, makes a total of $3.66 \mathrm{Km}$. This path allows for horse-back riding. The farmers offer this service because during the rainy season some sections of the trail can be very difficult to hike.

Throughout this trail the Apanas Lake and Gobiado La Peña are visible. One may find medicinal plants, trees of ecological interest, orchids, ferns, and a variety of vegetation. Watching fauna is also promising and the name of the trail is actually given from the local name of the howler monkey (Alluatta palliate).

"Campanero": This is the shortest trail in the site; it reaches 1600 meters starting at the foot of El Gobiado. The name is given because of the presence of a bird, commonly known as Campanero o Jilguero (Procnias trinculatta). This path is the easiest to hike, in comparison with the other two trails. Lots of birds, butterflies and other small animals can also be seen here. The vegetation, especially trees, is described for the local guides in terms of their uses and significance for the ecosystem.

\subsection{Visitor carrying capacity methodology}

The calculation of the visitor carrying capacity considers three levels: the physical carrying capacity (PCC), the real carrying capacity (RCC), and the effective carrying capacity (ECC). Each level constitutes a corrected estimation of the previous one based on the specific factors involved in each case studied. The relationship can be represented as follows: PCC $>$ RCC $\geq$ ECC [2].

In order to estimate of the above parameters, the following assumptions were made:

- Visitors go in one direction around the walking trail, completing a circuit.

- A person requires a minimum space to move freely, this is 1 lineal meter.

- The mean time needed to walk each trail in the NRMV, is as follows:

- El Puma: 4 hours

- $\quad$ El Crater: 1.5 hours

- El Cafetal: 0.75 hour

- The mean time needed to walk each trail in the NRDE is:

- El Congo: 3.5 hours

- El Leon: 2 hours

- Campanero: 1 hour

- The open hours to visitors in NRVM are from 8:00 to 16:00 hrs. This means that there are 8 hours available each day. In NRDE, they have established visitor hours from 7:00 to 17:00 hrs, 10 hours available each day. 


\subsubsection{Calculating the physical carrying capacity (PCC)}

The physical carrying capacity is the maximum number of visits that is possible to admit during a day. The figure is given by the relationship between the available space in the walking trail and the number of hours available to visit the site. A very simple equation is used:

$$
\mathrm{PCC}=\mathrm{S} / \mathrm{sp} * \mathrm{NV}
$$

where $\mathrm{S}$ is available surface, sp is the area used per person and NV number of times the site can be visited in a given day. This is calculated with: $\mathrm{NV}=\mathrm{Hv} / \mathrm{tv}$.

Where: Hv: Open hours, tv: required time to walk every trail.

\subsubsection{Calculating the real carrying capacity (RCC)}

The real carrying capacity is the maximum number of visits that is possible after applying a series of correction factors to the FCC. These factors are defined according to the particular characteristics of the site, considering physical, ecological, social and managerial variables [2].

The correction factors considered for this study were:

$\begin{array}{lll}\text { - } & \text { Social Factor } & \text { (FCsocial) } \\ \text { - } & \text { Erodability } & \text { (FCero) } \\ \text { - } & \text { Inundated sections } & \text { (FCacc) } \\ \text { - } & \text { Temporal closing } & \text { (FCctem) }\end{array}$

The general equation applied was:

$$
\mathrm{RCC}=\mathrm{PCC} * \mathrm{Fcx}
$$

Each correction factor was calculated applying the next equation:

$$
\mathrm{Fcx}=\frac{1-\mathrm{Mlx}}{\mathrm{Mtx}}
$$

where Fcx is Correction Factor of variable " $\mathrm{x}$ ", Mlx is Limiting magnitude of variable " $x$ " and Mtx is Total magnitude of variable " $x$ ".

To determine each of the factors field surveys were accomplished. For instance, for the soil erodability factor length and slope degree of all segments in the trails were measured in order to identify slopes higher than $10 \%$ and $15 \%$ [2].

\subsubsection{Calculating the management capacity (MC) of the reserve}

The management capacity is defined as the possibilities the administrators of a protected area have to develop the activities and be able to reach the objectives of the management plan. It is calculated as the mean value provided from the condition of the infrastructure, the equipment and the personnel. The MC is presented as a percentage of the optimum management capacity. The equation used was:

$$
\mathrm{MC}=\frac{\text { Infrastructure }+ \text { Equipment }+ \text { Personnel }}{3} * 100
$$

where MC is the management capacity of the protected area.

For the estimation of the management capacity variables such as legal frame, policies, equipment, competence of the staff, funding, infrastructure, and existing 
facilities are included. The variables considered for this study (infrastructure, equipment and personnel) were selected based on the priorities of the Management Plans of the two Natural Reserves [4, 6].

\subsubsection{Calculating the effective carrying capacity}

The effective carrying capacity is the maximum number of visits that should be allowed according to the capacity to manage them in the area $[2,3]$.

The equation used was

$$
\mathrm{ECC}=\mathrm{RCC} * \mathrm{MC}
$$

where ECC is Effective Carrying Capacity, RCC is Real Carrying Capacity, and $\mathrm{MC}$ is Management Capacity of the protected area.

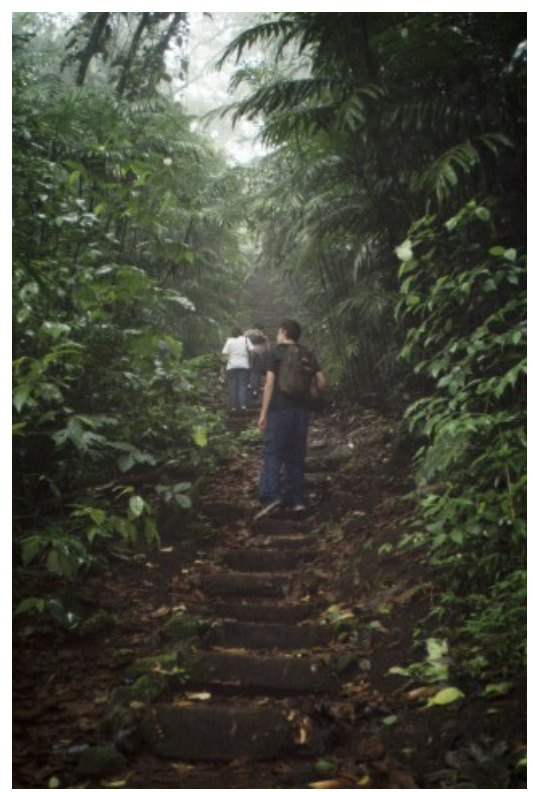

Figure 2: Tourists on the walking trail El Puma, RNMV, Granada, Nicaragua.

\section{Results and discussion}

\subsection{Natural Reserve Mombacho Volcano}

The Effective carrying capacity for the trail El Crater was estimated to be 442 visits/day, while in the trail El Puma it is only 93 visits/day (Table 1). The main constrain for the RCC is the Social factor. This factor reduces the PCC up to $87 \%$ in the trail El Crater and up to $95 \%$ in El Puma (Table 1). This difference is caused by the need to have more space between groups of visitors and less 
people by group, because the trail is more difficult to hike. On the other hand the trail El Cafetal shows the biggest carrying capacity of the three trails. However this trail was established with the purpose of giving an alternative to the tourists while they waited to be taken up the volcano (to the nucleus zone); where the two main walking trails are located. So it is not of much interest for the tourist to visit this trail.

To determine if the estimated tourism carrying capacity in this study was exceeded by the current visitation to Mombacho, the number of tourism visits actually taken (from site records of Fundación Cocibolca) was compared to estimated tourism carrying capacity calculations. This permits one to provide appropriate recommendations to tourist management so the number of site visits can be brought in line with ECC.

We found that the estimated carrying capacity had not yet been exceeded. But the pattern showed for the visitors to the Natural Reserve indicates a tendency for the number of visitors per day in peak periods to increase. For example March 2002 with 366 visits/day and June 2003 with 305 visits/day were the peak records, compared to the most visited days in 2001 and 2000, that did not exceed 280 visits/ day. Furthermore the ECC for students is only 236 visits/day; the current total number of visitors goes beyond this. For this reason it is recommended to the administrators of the reserve to take this factor in consideration when students are visiting.

Table 1: $\quad$ Tourism carrying capacity for the walking trails El Crater, El Puma and El Cafetal. Natural Reserve Mombacho Volcano, Granada.

\begin{tabular}{|c|c|c|c|c|}
\hline $\begin{array}{c}\text { CARRYING CAPACITY } \\
\text { (visits/day) }\end{array}$ & \multicolumn{2}{|c|}{$\begin{array}{l}\text { SENDERO } \\
\text { EL CRÁTER }\end{array}$} & $\begin{array}{l}\text { SENDERO } \\
\text { EL PUMA }\end{array}$ & $\begin{array}{c}\text { SENDERO EL } \\
\text { CAFETAL }\end{array}$ \\
\hline PHYSICAL (FCC) & \multicolumn{2}{|c|}{8000} & 8000 & 9067 \\
\hline Correction Factors & \begin{tabular}{|l} 
Eco \\
tourists
\end{tabular} & Students & & \\
\hline Factor Social: FCsocial & 0.1304 & 0.0698 & 0.0476 & 0.1304 \\
\hline Erodability: FCero & 0.8187 & 0.8187 & 0.6248 & 1.0000 \\
\hline Accessibility: FCacc & 0.8187 & 0.8187 & 0.6248 & 1.0000 \\
\hline Inundated sections: FCane & 0.9993 & 0.9930 & 0.9859 & 1.0000 \\
\hline Temporal closing: FCctem & 0.8571 & 0.8571 & 0.8571 & 0.8571 \\
\hline REAL (CCR) & 599 & 318 & 126 & 1014 \\
\hline \begin{tabular}{|c} 
MANAGEMENT CAPACITY \\
(MC)
\end{tabular} & & & $4.24 \%$ & \\
\hline $\begin{array}{l}\text { EFECTIVE CARRYING } \\
\text { CAPACITY (ECC) }\end{array}$ & 442 & 236 & 93 & 753 \\
\hline
\end{tabular}




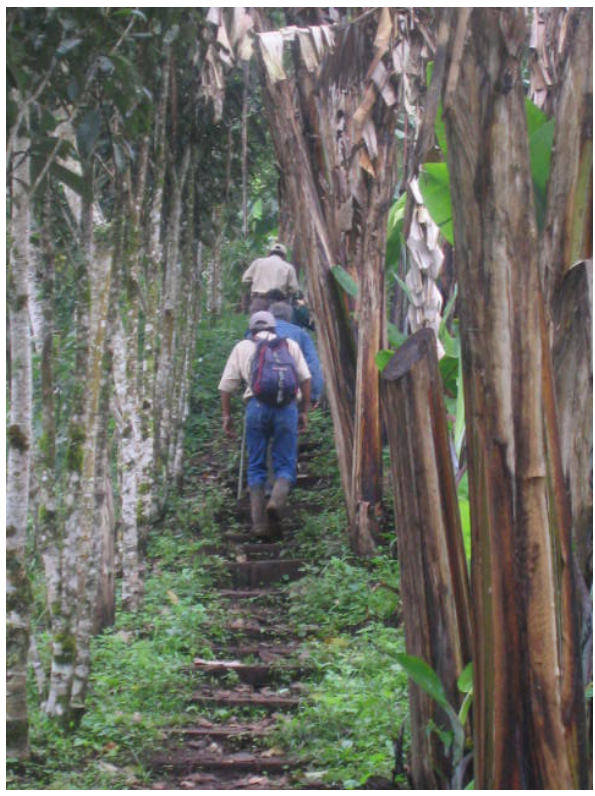

Figure 3: Tourists with guides in the walking trail El Leon, RNDE, Jinotega, Nicaragua.

Table 2: $\quad$ Tourism carrying capacity for the walking trails, Fila El Gobiado, Natural Reserve Datanlí-El Diablo, Jinotega.

\begin{tabular}{|c|c|c|c|}
\hline $\begin{array}{l}\text { CARRYING CAPACITY } \\
\text { (visits/day) }\end{array}$ & $\begin{array}{l}\text { SENDERO EL } \\
\text { CONGO }\end{array}$ & $\begin{array}{l}\text { SENDERO } \\
\text { EL LEON }\end{array}$ & $\begin{array}{l}\text { SENDERO EL } \\
\text { CAMPANERO }\end{array}$ \\
\hline PHYSICAL (FCC) & 7358 & 8611 & 7846 \\
\hline \multicolumn{4}{|l|}{ Correction Factors } \\
\hline Factor Social: FCsocial & 0.167 & 0.167 & 0.230 \\
\hline Erodability: FCero & 0.3607 & 0.4302 & 0.5803 \\
\hline Accessibility: FCacc & 0.3607 & 0.4302 & 0.5803 \\
\hline Inundated sections: FCane & 0.9900 & 0.9600 & 0.9900 \\
\hline Precipitation: FCprecip & 0.7700 & 0.7700 & 0.7700 \\
\hline Fauna: FCfauna & 0.5200 & 0.4600 & 0.5000 \\
\hline REAL (CCR) & 64 & 92 & 235 \\
\hline $\begin{array}{c}\text { MANAGEMENT CAPACITY } \\
\text { (MC) }\end{array}$ & \multicolumn{3}{|c|}{$62.34 \%$} \\
\hline $\begin{array}{l}\text { EFFECTIVE CARRYING } \\
\text { CAPACITY (ECC) }\end{array}$ & 40 & 57 & 146 \\
\hline
\end{tabular}




\subsection{Natural Reserve Datanlí-EI Diablo}

The effective carrying capacity for the trail El Leon was estimated to be 57 visits/day, while in the trail El Congo it should be limited to 40 visits/day (Table 2). The main constrain for the RCC is the Social factor. This factor reduces the PCC up to $83 \%$ in these two trails and $77 \%$ in the Campanero trail (Table 2). This difference is caused by the need to have more space between groups of visitors and less people by group, because the trails are more difficult to hike. Therefore, the accessibility and soil erodability factors are less restrictive in the trail Campanero. These are the reasons why this trail shows the biggest effective carrying capacity of the three trails. It has lower slope gradients and is easier to walk than the other two.

\section{Conclusions}

\subsection{General and methodological}

The number of visitors estimated with this methodology should not be used as a definitive restriction, but as an approximate appraisal that lets us know if it is desirable to slow down the visitor flow. The figure can also be used to support administrative decisions to decrease the number of visitors per day that are admitted to a site. This is especially pertinent when there are certain pressures for allowing many more visitors than the site should handle.

Visitor carrying capacity in a protected area varies according to the particular physical and ecological conditions, as well as the management capacity of the area. Therefore, if the management capacity of a particular area is improved it would increase its visitor carrying capacity. This allows flexibility to try new visitor management strategies.

The social factor has the main effect in reducing the RCC in all the walking trails. Another factor that influences the RCC is the accessibility within a trail. This is an indication of the relevance of these two factors and should be considered in the planning of the walking trails and for a discussion of the kind of visitors the ecotourism business is aiming for.

\subsection{Specifics for the two sites evaluated}

In the case of Natural Reserve Mombacho Volcano, if the trend of increasing visitation continues, it is recommended to more stringently structure the number of visitors per day, specially the students. This strategy will avoid excess use of the walking trails, and their consequent deterioration effects on the habitat.

In the case of Natural Reserve Datanlí-El Diablo it is recommended to follow the ECC figure as a reference. This is because the characteristics of the trails, and the fact they are not covered with any protective material (like they are in Mombacho), make the site more susceptible to deterioration when visitation numbers surpass the suggested thresholds.

Management capacity can be improved in both reserves, if the appropriate infrastructure and equipment were to be acquired. Also it is contingent upon 
those personnel who are managing the visitors, to receive general and specific training that improves their competence in the topics they have to deal with.

Establishment of a monitoring system to follow up the conditions in the reserves is recommended. This will allow for avoidance of degradation of the natural resources to a point where it will be too expensive (calculated as time and money) to try to recover them.

\section{References}

[1] Buitelaar, R. M. Clusters ecoturísticos en América Latina: Conclusiones de una conferencia internacional. Comisión Económica para América Latina (CEPAL), Santiago, Chile. 2001.

[2] Cifuentes, M.; Mesquita, C.; Méndez, J. Capacidad de Carga Turística de las Áreas de Uso Publico del Monumento Nacional Guayabo, Costa Rica. WWF-Centroamérica. 75 p, 1999.

[3] Cifuentes, M. Determinación de Capacidad de Carga Turística en Áreas Protegidas. WWF-CATIE. Costa Rica. 26 p, 1992.

[4] Fundación Nicaragüense para la Conservación, Fundación Cocibolca (FUNCOC). Plan de Manejo Reserva Natural Volcán Mombacho Granada, Nicaragua. 204 p, 2003.

[5] Kuss, F.; Graefe, A.; Vaske, J. Visitor Impact Management. National Parks and Conservation Association. 256 p, 1990.

[6] MARENA. Plan de Manejo de la Reserva Natural Cerro Datanlí -El Diablo. Ministerio del Ambiente y Recursos Naturales. MARENA. Sistema Nacional de Áreas Protegidas. SINAP. Managua, Nicaragua. 124 p, 2002.

[7] MARENA. Zeas Maura, M.; Quintero, B.; Sánchez, M.; Motas, S. Ministerio del Ambiente y Recursos Naturales. Informe Nacional de Áreas Protegidas. Managua, Nicaragua. 35 p, 2002.

[8] SINIA. Sistema Nacional de Información Ambiental Nicaragua. Web page: http://www.sinia.net.ni/index.asp. Interactive maps: Mapa de areas protegidas, 2004. Managua, Nicaragua.

[9] Somarriba, M. Parra. O.; Acuña, A. Potenciales impactos ambientales de actividades eco turísticas en áreas protegidas en Nicaragua. Una revisión. Becas Keizo Obuchi - UNESCO. Universidad Nacional Agraria, Nicaragua y Universidad de Concepción, Chile. 33 pp, 2002. 